\title{
SUPREME COURT EFFECTIVENESS AND THE POLICE ORGANIZATION
}

\author{
NeAL A. MiLNER*
}

This article emphasizes the limits of the effectiveness of Supreme Court-imposed restraints on police behavior. It argues that such effectiveness is mitigated by the milieu in which the police officer operates, by the characteristics of the police decisionmaking process, and by the relationship police have with their reference groups.

The focus is not upon the Supreme Court, nor upon any single court decision. Rather it is upon the everyday activities of the police organization. It emphasizes organizational analysis because "the language of courts is given meaning through a process mediated by the organizational structure and perspective of the police."1 There is a risk involved with arguing that common police behavior and attitudes mitigate the effectiveness of these rules because "common" is a difficult word to define and a difficult concept to quantify. It is used here to connote activity that is prevalent, widespread, and typical.

This emphasis on the police organization is accompanied by an emphasis on the uncertain nature of compliance with formal rules. Within bureaucratic organizations such as the police there is an inherent and basic tension between the attempt to impose formal rules and the members' recalcitrance to adopt changes in behavior in order to implement these rules. ${ }^{2}$ Rules, of course, are characteristic of all bureaucracies, and tension evolves from the inherent difficulty of applying general rules to specific situations. Rank and file bureaucrats typically have at their disposal a wide variety of methods that they can use to cope with this tension and limit the rules' effectiveness. ${ }^{3}$ In addition, there are special characteristics of police bureaucracies that increase the tension between rule and implementation.

* Assoc. Professor of Political Science, Grinnell College.

I would like to thank Jerome H. Skolnick, Joel Grossman, and William K. Muir, Jr. for their useful comments on an earlier draft. I would also like to thank Meredith Dodge for her able research assistance.

${ }^{2} \mathrm{~J}$. Skolnick, Justice Without Trial 219-20 (1966). Many of the ideas in this paper come from this source, but it is different from Skolnick's work in two important ways. First, it is more encompassing in its discussion of interrogations. Second, it attempts to take a broader perspective on the police organization. Other studies emphasizing organizational analysis of the police are Reiss \& Bordua, Environment and Organization: A Perspective on the Police, in The Police: Six Socrological Essays 25 (D. Bordua ed. I967); and, less explicitly, J. Gardiner, The Politics of Corruption (1970).

${ }^{2}$ R. Merron, Soctal Theory and Social Structure (I957); Selznick, Foundations of the Theory of Organization, 13 AMr. Soctological Rev. 25 (1948). This view of bureaucracy is summarized in N. Mouzelis, Organisation and Bureaucracy 59-62 (I968).

${ }^{8}$ See R. Peabody, Organtzational Authority (1964). The merging of these views on the relationship between law and organization is apparent though not thoroughly developed in Levine's useful critique of studies of the Supreme Court's impact. He argues both that the Court's impact is problematic and that scholars should take an increased interest in the relationship between the efficacy of legal rules and organizational factors such as the "lines of command within institutions and the conditions under which bureaucratic resistance to innovation such as legal change are broken down." Levine, Methodological Concerns in Studying Supreme Court Efficacy, 4 LAw \& Soc'x REv. 583, 591 (r970). 
The concern here is with the rules made by the United States Supreme Court in its decisions pertaining to the exclusion of evidence in criminal trials, ${ }^{4}$ and, most explicitly, with those rules involving searches and seizures and interrogations. The Supreme Court has increasingly relied upon the exclusion of illegally obtained evidence as a means of regulating police behavior. ${ }^{5}$ A detailed description of the case law in these areas is not necessary for our purposes; ${ }^{6}$ it is only necessary to illustrate what the interrogation and search and seizure rules have in common. Their commonality is related to the general goals of the court decisions:

I. The decisions attempt to regulate police behavior by formalizing police procedures (e.g., more search warrants, more use of a standard warning about rights to have counsel and remain silent).

2. They attempt to restrain the police by requiring that such procedures be used consistently and not at the whims of police officers.

3. The sanctions accompanying these rules are based on the proscribing of evidence obtained contrary to these rules. Thus, the sanctions do not apply directly against the police officer.

The first part of this article looks at certain aspects of what Skolnick calls the policeman's "working personality"- that is, the way he sees his work and the occupational ideology he develops. This ideology and the milieu in which it develops foster both a distrust for due process-oriented change and a defensiveness toward its advocates. Part II looks at the typical characteristics of the police decisionmaking process and shows that this process is characterized by police adoption of their own standards of legality that are different from the Court's. Part III investigates the relationship between the police and their important reference groups and shows that these relationships tend to reinforce this distrust and to encourage mitigating behavior.

\section{Working Personality, Occupational Mitieu, and Ideology}

The police clearly have a negative attitude toward the predominant trend in Supreme Court decisions affecting their behavior. Over eighty per cent of the officers in four Wisconsin police departments disapproved of the Miranda decision. ${ }^{7}$ Ninety per cent of a sample of officers in three larger cities thought that the Court decisions had gone too far, while a sample of officers working in the ghettos of eleven large

\footnotetext{
The two most important decisions are Mapp v. Ohio, 367 U.S. 643 (196I) and Miranda v. Arizona, 384 U.S. 436 (1966).

EFor a brief discussion of these other sanctions see W. Chambliss \& R. Seidman, Law, Order, and POWER 368-9x (x97x).

'For descriptions of the Court's interrogation decisions, see N. MILNER, The Court and Local. Law. ENFORCEMENT 26-47 (1971). A dated but still useful study of search and seizure case law is Allen, The Exclusionary Rule in the American Law of Search and Seiztre, in Police Power and IndividunL Freedon 77 (C. Sowle ed. 1962).

${ }^{7}$ MiLNER, supra note 6 , at 197 .
} 
northern cities saw limitations imposed by these decisions as probably the most serious obstacle they face. ${ }^{8}$

While this is rather good evidence that the police do not appreciate outside interference with the performance of their job, that explanation alone conceals some of the more important and pervasive reasons for these objections. It does not explain why there is such disapproval despite the fact that virtually all studies of the effects of these decisions suggest that they do not hamper police activities nearly as much as the police claim. Moreover, it is imperative to know why the police are so concerned with crime investigation when most officers spend very little time on such activities. An investigation of police perceptions of social reality, organizational attempts at dealing with these perceptions, and the results of these attempts gives additional insight into the reasons for the amount of distrust and defensiveness toward legal change.

The primary goals of the police organization are intangible, ambiguous, and contradictory. This ambiguity is to a great extent an integral part of a policed society that espouses democratic norms. ${ }^{9}$ On the one hand, society asks the police to maintain peace and order, but, on the other, the Rule of Law requires that obstacles be established lest this job be done too efficiently. There is thus an important and inherent conflict between efficiency and restraint. ${ }^{10}$ Because these two concepts are themselves intangible and difficult to measure, society itself has great difficulty in determining acceptable police behavior. ${ }^{11}$

Bureaucracies are often burdened by conflicting goals. Accordingly, it is not surprising that police organizations should experience goal conflict. ${ }^{12}$ Yet conflict need not always be destructive; it can lead to positive outcomes if handled properly. By recognizing that such conflict is both endemic and legitimate, a police officer might more readily accept the need for restraint. This attitude, however, seems atypical.13 In police organizations, the way conflict between efficiency and restraint is handled tends in fact to undermine rank and file acceptance of the Rule of Law.

\footnotetext{
${ }^{\mathbf{8}}$ Reiss, Career Orientations, Job Satisfaction, and the Assessment of Law Enforcement Problems by Police Officers, in II Studies of Crime and Law Enforcement in Major Metropolitan Areas (Report submitted to the President's Commission on Law Enforcement and the Administration of Justice, Ig67), $\$ 2$, at 109. A recent poll conducted for the San Francisco Police Department shows that $90 \%$ of its officers felt the courts had gone too far. San Francisco Chronicle, Aug. 3I, r97I, at I, col. 4.

- For an historical discussion see Silver, The Demand for Order in Civil Society, in BonduA, supra note $I$, at $I$.

${ }^{10}$ Skolnick, sispra note I, at I-22; H. Packer, The Limits of the Criminal Sanction i $499-246$ (1968).

12 This point is generally discussed in Thompson \& McEwen, Organizational Goals and Environment: Goal Setting as an Interaction Process, 23 Am. Sociological Rev. 23 (1958).

12 For an interesting study of another law-implementing organization undergoing goal conflict, see P. Nonet, Administrative Justice (r969). See also the discussion of conflict-avoidance and its mitigating effect on the Supreme Court's school prayer decisions in $K$. Dozbeare \& P. Hamamond, The School Prayer Decision: From Court Poltcy to Local Practice (I971).

${ }^{13}$ But see W. Muir, Jr., The Development of Policemen 8-II (paper presented at the annual meeting of the American Political Science Association, Los Angeles, Sept. 8-12, 1970). Although the empirical evidence needed to buttress this informative study is as yet incomplete, Muir shows that on the basis of preliminary testing officers with these characteristics would seem to be in the minority.
} 
The police typically make a moral distinction between the laws made to constrain individual behavior, the enforcement of which they see as their paramount task, and laws that constrain police authority and responsibility. The latter constraints are seen as a far less important part of their occupational morality. Thus, Court decisions that seem contrary to these norms of police morality foster a greater alienation from the morality of due process and the Rule of Law. ${ }^{14}$

The police have characteristics that initially make them amenable to the development of such isolation and alienation. They are quite homogeneous in religious, class, and ethnic background. The same ethnic groups continuously predominate. Not surprisingly, accompanying this social isolation is a police subculture that places strong reliance on other police officers as reference groups. This strong sense of cohesion is reinforced by the need to rely on other officers for protection and by the general isolation of the policeman's work. This subculture has a profound and lasting effect on the socialization of police officers. ${ }^{15}$

Homogeneity and isolation foster an intolerance of perspectives that differ from the policeman's own. ${ }^{16}$ This is an important factor in understanding police views of the due process trend because this background and social isolation makes them initially less likely to appreciate the uncertainties and subtleties of legal constraints and more likely to attribute the difficulties of police work in general to the leniency of court decisions. ${ }^{17}$ The occupational ideology reinforces this distrust of legal change and exacerbates it. Perhaps more significantly, the reaction to legal constraints is also closely tied to the way the police feel about the law's relationship to their responsibilities. As do most workers, the police seek more occupational responsibility. Morale is severely threatened when a worker feels that his responsibility is being reduced. ${ }^{18}$ The police occupational ideology considers legal restraints not as a means of increasing but rather as a means of limiting the amount of proper responsibility. The police see as their model police officer one who is actively engaged in upholding substantive law by apprehending those who violate law and disdain authority. Search and interrogation are perceived as so integral a part of this model officer's work that their usage is considered a basic affirmation of the police officer's image. A limit

\footnotetext{
1t Skolnick, supra note $I$, at I96. The relationship between the moral authority of the criminal law and its enforcement is discussed in Skolnick, Coercion to Virtue, $4 \mathrm{I}$ S. CaI. I. Rev. 588, 626.29 (1968). A theory of police deviancy that has some relevance to the discussion of police alienation from the moral authority of procedural law is found in Chambliss \& SeIDMan, supra note 5, at 358-66.

${ }^{18}$ McNamara, Uncertainties in Police Work: The Relevance of Police Recruits' Background and Training, in Bordua, supra note $I$, at 163 ; Chambliss \& Seidman, supra note 5, at 362-66.

${ }^{16} \mathrm{On}$ isolation and intolerance see Swett, Cultural Bias in the American Legal System, 4 LAw \& Soc'y Rev. 79 (1969); Hudson, Police-Citizen Encounters that Lead to Citizen Complaints, 18 Soc. Prop. I79, I82-84 (1970); SkolNick, JUSTICE Without Trial, supra note 1 , at 49-54; McNamara, supra note 15, at 193-95. For a discussion of the stability of ethnic group dominance of police departments, see Wilson, Generational and Ethnic Differences among Career Police Officers, 64 AM. J. Socrozocy 522 (1964).

${ }^{17}$ McNamara, supra note 15 , at 196-97. For supporting survey data, see Reiss, supra note 8, at 118.

${ }^{18}$ D. Katz \& R. Kahn, The Social Psychology of Organizations $363-64$ (1964).
} 
on their use is thus perceived not merely as a job constraint but rather as a basic threat to the police officer's occupational raison d'etre. ${ }^{19}$

The sense of threat is increased because the very crimes requiring the type of investigation seen as closest to the model behavior of a police officer are frequently involved in appellate court decisions. ${ }^{20}$ The enforcement of these laws concerning crimes without victims, especially narcotics violations, creates some of the stickiest search and interrogation issues. One might expect that, as a result, the police would be anxious to have these laws eliminated. This is clearly not the case, at least partially because such elimination is viewed as a threat to worker responsibility. Thus, because of their symbolic importance, the police disdain the willingness of reformers to eliminate these attempts at coercion to virtue. ${ }^{21}$

The link between substantive and procedural reform further exacerbates police distrust of change imposed from the outside. The police occupational milieu fosters a view of social reality that lumps these advocates of law reform into one group because changes in procedural as well as in substantive law gives the criminal more weapons and reduces basic police responsibility. ${ }^{22}$ Skolnick is certainly correct in his assertion that the police officer has a craftsman's bias against outside interference, ${ }^{23}$ but the craftsman in this case does not see advocates of legal change

\footnotetext{
${ }^{10}$ Skolnick, JUstice Wirhout Trial, supra note $I$, at 2I5; Swett, supra note 16 , at 87-88; Skolnick \& Woodworth, Bureaucracy, Information and Social Control: $A$ Study of a Morals Detail, in BorDos, stspra note I, at I29. Police morale is best discussed in Wilson, Police Morale, Reform and Citizen Respect: The Chicago Case, in Bordor, supra note I, at I37. See also Pepinsky, A Theory of Police Reaction to Miranda v. Arizona, 16 Crime AND Delinguency 379 (I970). Muir, supra note 13, briefly discusses the formation of police occupational models. On occupational models generally see Fox, Training for Uncertainty, in The Student-Physician 215 (R. Merton, G. Reader, \& P. Kendall eds. 1957). Fox shows how the medical student is taught that uncertainty, ambiguity, and doubt are a legitimate part of the medical profession. His teachers stress the fact that they frequently have doubts about diagnosis.

${ }^{20}$ Although the Court does not explicitly consider the type of crime as a mitigating circumstance, the police surely do. See Packer's discussion of "constitutionalization" in Packer, Who Can Police the Police?, New YoRK Review of Books, Sept. 8, 1966, at Io.

21 See, e.g., Ker v. California, 374 U.S. 23 (I963); A. Lindesmith, The Addict and the Law 36-37 (1965); Skolnick, Coercion to Virtue, supra note 14 . Gambling offenses were involved in $86 \%$ of the search warrants issued in Detroit during the years $1956-63 ; 98 \%$ of the search warrants issued in New York City in 1963 were either for gambling or narcotics offenses. See L. Tiffany, D. McIntyre, \& D. Rotenberg, Detection of CrIME IO0-03 (I967). A recent poll of San Francisco police officers showed that $95 \%$ opposed legalization of marijuana. San Francisco Chronicle, Aug. 3r, I97r, at I, col. 4' It is noteworthy that such police unanimity is found in a city whose inhabitants and culture are known to be more tolerant of deviance than any other city in the country. Of course, attitudes may not reflect behavior, and the San Francisco police may not crack down very hard on pot smokers, but the point is worth further investigation. Becker \& Horowitz, The Culture of Civilty, in Culture AND Civility IN San Francisco 4 (H. Becker ed. I97I).

${ }^{22}$ For further development of this point see Milner, Police Responses to Legal Change, in Police IN Urban Society 247 (H. Hahn ed. I97I); Wilson, Police Morale, Reform, and Citizen Respect, in The Politics of Protest ch. VII (a Staff Report presented to the National Commission on the Causes and Prevention of Violence, J. Skolnick ed. 1969) [hereinafter cited as Polirics of Protest]; D. Bouma, KIDs AND Cops 26-28 (Ig69). An example of this view of social reality can be found in the writings of W. Cleon Skousens, a former Salt Lake City police chief and an editor for Law and Order magazine. See Skousens, I7-19 LAW \& ORDER (23 part series, 1970-1972). These articles read like responses to Hugh Heffner's Playboy philosophy and, alas, are about as lengthy.

${ }^{23}$ SxolNick, Justice WIthout TRIAI, supra note $\mathrm{I}$, at III.
} 
merely as sidewalk superintendents. Instead he sees them as a threat to the fundamental operating rules of the craft. ${ }^{24}$

One of the less subtle ways that police organizations attempt to deal with this conflict is to reinforce these predominant views by emphasizing efficiency at the expense of restraint. One reason for this choice of emphasis is that it is relatively easier to measure output reflected by the number of people arrested and the number of crimes solved than it is to measure, for example, the number of people whose rights were protected. In a sense measurement determines goals. ${ }^{25}$

The preceding discussion, however, suggests that this explanation alone begs the question. It is certainly naive to think that police emphasize order and efficiency over legality merely because of measurement problems. Police statistics reflect what police officials themselves believe and what they think the public believes is most important. In any case, this emphasis further reinforces the policeman's view that legal constraints are receiving undue attention on the outside.

Even the more progressive and enlightened police organizations reinforce this view. Indeed, they emphasize law in their training programs, but, paradoxically, they do so in a way that increases the officer's distrust of legally imposed restraint. To overcome distrust and uncertainty, these departments emphasize overly literal interpretations of the law. ${ }^{20}$ There are two consequences resulting from this style of presentation, and both work against the acceptance of the legitimacy of legally imposed restraint.

One consequence is that this interpretation of the certainty of specific legal rules tends to foster a perspective which stresses the certainty of the law. This increases police cynicism and distrust of legal change because "each new reversal of hallowed legal principles upon which the code of police work rests, strips away some of the majesty of the body of the law ..." .27 But, as we shall see more clearly in the subsequent discussion of police decision-making, the police are typically not surprised at the law's ambiguity. Their street experiences constantly demonstrate this uncertainty; they simply do not accept it as legitimate. Thus a second consequence is that they view legal constraints as unrealistic and tend to denigrate training programs that stress legal rules. $^{28}$ As a New York police officer put it, "You go to the [training] academy and get all the bullshit, and you come out on

\footnotetext{
${ }^{24}$ This may help explain why the police consider lack of external support for their work to be the most serious problem facing individual officers. While $48 \%$ of a sample of policemen claimed that this lack of support was their most serious problem, the next highest choice received only $21 \%$. See NAtional Advisory Commassion on Civil Disorders, Supplemental Studies for the Nattonal Advisony Commission on Civil Disorders i03-06 (I969).

${ }^{26}$ A. Etzioni, Modern Organizations 9-Io (1964). For a criticism of police statistics along the same lines, see Newman, The Effect of Accommodations in 7ustice Administration on Criminal Statistics, 46 Sociology \& Soctal Research I44 (1962). See also Skolnick, Justice Without Triat, supra note $x$, at 164 .

${ }^{26}$ McNamara, supra note 15, at 250-5I.

27 A. Niederfoffer, Behind the Shield: The Police in URban Society i64 (I967). See also Milner, Common Police Résponses to Legal Change, supra note 22.

${ }^{28}$ MeNamara, supra note 15 , at 164 .
} 
the street and you're in a whole different world."29 This characteristic attitude of the police subculture continues to predominate.

The pervasive and vigorous distrust manifested by the rank and file police officer and the training program's failure to reduce this distrust may force the leaders of the police organization into a third strategy that comes closer to the not-very-subtle strategy discussed initially. Faced with a severe morale problem resulting partially from responses that link legal change to more basic societal problems, the police administrators may believe that it is essential to take the views of their men in denigrating the Court's decisions.

Law enforcement's emphasis on the goals and the ideology of professionalism can be seen as one attempt to boost police morale by limiting the influence of outsiders. Although the police may not be a "profession" as the concept is formally employed by social scientists, ${ }^{30}$ the police do advocate the goals of a form of professionalism that emphasizes technical competence, specialization, and impartiality. ${ }^{31}$ This ideology further exacerbates the distrustful atmosphere by stressing the necessity of isolating the police from outside interference with their tasks. ${ }^{32}$

In short, the police occupational milieu fosters at best a view that the law is unrealistic and at worst a view that encourages police to evade the rules related to interrogation and search.

\section{II}

\section{The Police Decision-Making Process}

James $\mathrm{Q}$. Wilson argues that the police are best characterized as subprofessionals who (I) work alone and (2) exercise wide discretion in matters of vital importance (3) in a hostile environment. ${ }^{33}$ These three typical characteristics of the decisionmaking process are all crucial factors mitigating the effectiveness of legal constraints.

\section{A. Working Alone: The Limitations of Command and Control in a Semi-Military Organization}

The police officer's isolation from his supervisors is a crucial limitation on controlling rank and file behavior. Police rhetoric stresses the need for strict

\footnotetext{
${ }^{20}$ R. Whittmore, Cop! A Close-up of Violence and Tragedy 7I-72 (I969).

${ }^{80}$ W. Moore, The Professtons: Roles and Rules (i970); J. Wilson, Varieties of Police Behavior 283 (Ig68).

${ }^{31}$ A look through Police, Police Chief, or Law and Order magazines clearly demonstrates this emphasis. A good example is Davis, Professional Police Principles, Police CHIEF, May 1970, at 8-9, 55-56. Davis is the chief of the Los Angeles Police Department.

${ }^{39}$ There is vigorous debate about the effectiveness of police professionalization. Those most opposed to greater police professionalization with its emphasis on self-regulation are P. JACOBs, PRELUDE TO Riot (r968); Waskow, Community Control of the Police, Trans-Action, Dec. 1969, at 4-7; Milner, The Biases of Police Reform, in Black Politics-The Inevitability of Conflict: Readincs i59 (E. Greenberg, N. Milner, \& D. Olson eds. I97I). Mixed and sometimes contradictory views are found in Niederhoffer, supra note 27 , at I0-32, I62. See Skolnick, JUstice WIthout Trial, supra note I, at 235-39, for a concise discussion of the goals of police professionalization.

${ }^{3 a}$ Wilson, Varieties of Polyce Behavior, supra note 30 , at 30-32.
} 
subordination and hierarchical control; obedience is the watchword. Indeed, compared to members of other local public bureaucracies, police may be more likely to claim that they will accept orders in situations where they disagree with their supervisors or find their orders improper. ${ }^{34}$ But the isolation of the officer limits the importance of this claim because the situation described is rather hypothetical. His isolation means that typically such explicit orders, whether acceptable or not, cannot be given. ${ }^{35}$

The isolation of the police is an important mitigating factor for several reasons:

I. It limits the degree that policy change can be imposed from above.

2. It increases the importance of the rank and file police officer's own interpretation of a situation involving potential use of searches and interrogations. $^{36}$

3. It increases the likelihood that the officer's own goals may determine his behavior regarding interrogation and search, and thus it increases the possibility that Court goals will be displaced.

Police isolation has another dimension. Police departments themselves are isolated from public scrutiny. Thus another implication of isolation must be added:

4. Despite their own difficulties at command and control, the upper levels of the police bureaucracy are relatively free to make the general policy decisions that are supposed to guide rank and file behavior. ${ }^{37}$

Police isolation makes discretionary behavior a more important mitigating factor because crucial police decision-making occurs at a relatively unsupervised and unstructured level.

\section{B. Police Discretion}

The question of police discretion is central to the conflict between the principles of law and the maintenance of order. ${ }^{38}$ Search and interrogation are an integral part of this issue of discretion because both practices are so thoroughly intertwined with the role of suspicion.

Police work depends upon the ability to develop reliable indicators of suspicious behavior. The development of stereotyping behavior is crucial to the effective use of police suspicion. It allows an officer to anticipate the criminal act and thus

\footnotetext{
34 Peabody, supra note 3 , at ro4-rg.

${ }^{35}$ Reiss and Bordua, supra note I, at 57-58; Wilson, Varieties of Police Behavion, supra note 30, at 57-82. Wilson correctly argues that this lack of control is more prevalent in situations involving the maintenance of order (e.g., family quarrels, disturbing the peace) than it is in situations involving more clear-cut law enforcement situations. Nonetheless the isolation of the police officer in law enforcement situations involving search and seizure and interrogations is very great. See SkolNick, Justrce Without Trial, supra note I, at I4.

${ }^{30}$ See Etzron, supra note 25, at 75, for a discussion of how individual knowledge limits the degree of hierarchical control in organizations.

at See Wilson, Varieties of Police Behavior, sitpra note 30 , at 5.

${ }^{s 8}$ Skolnick, Justice WIthout Trial, supra note $\mathrm{I}$, at $\eta \mathrm{I}$.
} 
stop it before it occurs. It also gives him an indication of the kind of person to look for after the commission of a crime for which there is no suspect and for which very little physical evidence is available. The latter is the typical situation the police officer faces. ${ }^{39}$ The police organization encourages suspicion and stereotyping, and the good officer is one who develops these tools. Indeed, they are seen as fundamental operating rules for the maintenance of societal order.

Both the search and seizure and the interrogation rules can directly impinge upon the officer because the rules require that certain procedures be followed by a police officer despite the degree of police suspicion or despite the extent to which the officer is convinced of the suspect's guilt. Discretion and the use of stereotypical behavior patterns encourage the police to feel that they are in a better position to determine guilt than the more socially distant judges and prosecutors. ${ }^{40}$ As such, the efficacy of the Supreme Court decisions depends on the degree to which they limit this police discretion-and therefore the corollary that the Court's effectiveness depends upon the methods that the police can use to circumvent these limitations.

There is evidence to suggest that these Court-made rules have somewhat limited police discretion in both search and interrogation behavior. Formal procedures are now used far more commonly. Prior to the 196r Mapp decision search warrants in New York City were hardly ever issued, but in 1963 over 5000 search warrants were issued. ${ }^{41}$ Studies of the aftermath of Miranda unanimously show that police are now less likely to use discretion in deciding whether a person should be advised of his rights to remain silent, have an attorney, and have the state pay for counsel if he is indigent. ${ }^{42}$ The following statement made to the author by an experienced detective clearly illustrates this increased sensitivity:

You know, I learn something after every interrogation. I now know that if I go to get a suspect a cup of coffee, or leave the room, I should record the time. Otherwise, the suspect can say we held him for many hours. I guess the Miranda decision has made me more concerned about this. ${ }^{43}$

The statement by the detective also implies that the effectiveness of the rules will be optimal in situations where the police have arrest and, more indirectly, successful prosecution as their goals. The officer in the street, however, has wide discretion in determining a course of action in a particular situation, and he often chooses tactics and goals the success of which does not depend on arrest and

${ }^{30}$ See especially Matza's discussion of the "essential thief" in D. Matza, Becoming Deviant x82-95 (xg69), and Skolnick's discussion of symbolic assailants in Justice WITHOUT TrIaI, supra note $I$, at $45-48$.

${ }^{10}$ On searches and seizures see SkoLNICR, Justice WITHour Trial, supra note $x$, at 228; on interrogations see Milner, Police Responses to Legal Change, supra note 22.

11 Tiffany, McIntYre, \& Rotrenberg, supra note 2I, at Ioo.

"See, e.g., Wald, Ayres, Hess, Schantz, \& Whitebread, Interrogations in New Haven: The Impact of Miranda, 76 Yale L.J. 1519 (I967) [hereinafter cited as Wald]; Medalie, Zeitz, \& Alexander, Custodial Police Interrogation in our Nation's Capital: The Attempt to Implement Miranda, 66 Mrch. L. REv.

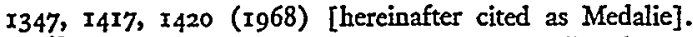

18 Interview with a Madison, Wisconsin, police detective in August, 1966. See MrLner, ThE CourT AND Local Law ENFORCEMENT, supra note 6, at 2 I0. 
prosecution.4 Chief Justice Warren himself recognized how this discretion mitigates the Court's effectiveness. Regarding the Court's attempts to limit police discretion in street searches and interrogations, the Chief Justice said:

[A] stern refusal by this Court to condone such activity does not necessarily render it responsive to the exclusionary rule. Regardless of how effective the rule may be where obtaining convictions is an important objective of the police, it is powerless to deter invasions of constitutionally guaranteed rights where the police either have no interest in prosecuting or are willing to forego successful prosecution in the interest of serving some other goal. ${ }^{45}$

It is perhaps now appropriate to examine the everyday activities of police departments from the perspective of how search and interrogation rules are compromised by four pervasive departmental objectives: authority maintenance, selfprotection, information, and harassment.

x. The Establishment and Maintenance of Authority. When they interact with citizens on the street, the police view the need to establish authority as the first and foremost objective. Authority is the prerequisite for control. Getting the upper hand not only may avoid violence but also affords the police officer the best opportunity to get the citizens involved to accept the policeman's interpretation of the situation. This profoundly affects the use of arrest. Control may not at all depend on arrest even in situations where, according to legal criteria, a valid arrest is possible. In such situations the officer often decides that there is a better way to handle the conflict or to solve the problem. Reasons for this decision can vary from a sympathetic view that formal arrest and all of the accompanying hassles would do the citizen more harm than good, to laziness on the part of the officer who does not want to take the time for court appearances. Whatever the reason, the ability to make such considerations is an integral part of the policeman's everyday behavior. ${ }^{40}$

Second, the importance of control over the situation may mean that an officer is willing to make an arrest not so much because he hopes that successful prosecution will result but because he believes that the demeanor of the citizen may warrant this use of the police officer's power. The officer arrests a citizen to show him who is boss. It should be emphasized that this behavior is not necessarily manifested by a highly authoritarian police officer who is out for revenge. The police often feel that the failure to handle the citizen in this manner will be interpreted by others as backing down and will thus discourage these others from future deference to his authority. There is evidence to suggest that the police are correct in this perception. ${ }^{47}$

\footnotetext{
it Skolnick, Justice Without Trias, supra note $\mathrm{r}$, at I62.63.

18 Terry v. Ohio, 392 U.S. I, I4 (I968) (emphasis supplied). See also Wilson's discussion of the limits of the use of the law as a guide to police behavior in VARIETIEs of PoLICE BeHavior, supra note 30, at 30-3I, 34-35, 52 .

${ }^{4}$ See Wilson, Varieties of Police Behavion, supra note 30, at 36-37; Werthman \& Piliavin, Gang Members and the Police, in BorduA, stupra note 1 , at 56, 88-93. A highly informative discussion of the decision to arrest as it applies to police activities in skid row is found in R. NIMmER, Two MiLLuon UNNECESSARY ARRESTS (I97I).

${ }^{47}$ See, e.g., Hudson, supra note 16 , at $189-9 \mathrm{x}$. The extraordinary importance of deference in police-
} 
Thus, even when an officer does make an arrest, he may not be interested in successful prosecution. ${ }^{48}$ This lack of concern with the quality of the arrest is not merely an aberrant aspect of the police subculture. It is sanctioned by the police organization whose statistics reflect a greater interest in measuring effectiveness by the percentage of crimes for which arrests have been made rather than by the percentage of crimes that ultimately lead to conviction. Moreover, the police organization itself accepts this use of arrest.

2. Self-Protection. Self-protection is another goal that pervades police activity. The element of danger greatly concerns the police officer, and much of his concern with the establishment of authority stems from the fear of danger. ${ }^{49}$ When selfprotection becomes an important enough goal, legal formality becomes less relevant.

There has been surprisingly little investigation of the relationship between this goal and the effectiveness of legal rules. The facts of a recent Supreme Court case involving an officer's right to conduct a protective search probably illustrates such mitigating behavior.

The case involved a plain-clothes officer who spent an evening in a restaurant observing the behavior of a suspected narcotics user. Though the suspect talked continuously with known users, the officer never saw objects actually pass between them. Subsequently, the officer identified himself and told the suspect to step outside, whereupon he said to the suspected user, "You know what I want." Mumbling unintelligibly, the suspect then reached into his coat pocket. The officer immediately grabbed the suspect's hand and pulled some packets of heroin from the man's pocket. Claiming that the man might have been reaching for a weapon, the officer argued that the search of the man's pocket was constitutional and thus its fruits were admissible because the search was necessary for the officer's protection. The Supreme Court, however, ruled that the evidence was illegally obtained because there were not sufficient grounds to believe that the suspect actually carried a weapon and because, even if there were such grounds, the search technique of reaching into the pocket impermissibly exceeded a "limited patting of the outer clothing."

It is conceivable that the assertion of self-protection was a means of avoiding the formalities of the exclusionary rule, but the truth of the officer's reasons for search are not the issue here. What is relevant for our purposes is the clear implication that if a policeman defines a search as necessary for self-protection, he is

citizen interactions is discussed in Black \& Reiss, Patterns of Behavior in Police-Citizen Transactions, in II Studies of Crime and LAw Enforcenent in Major Metropolitan Areas, 5 I, at 57-59 (Report submitted to the President's Commission on Law Enforcement and the Administration of Justice, 1967). For a discussion of the ways police and involved citizens differ in their perceptions of such interactions, see D. Bayley \& H. Mendelsohn, Minorities and the Police I22-29 (I969).

${ }^{8}$ It is impossible to get any useful general data showing the percentage of those arrested who are ultimately charged.

${ }^{40}$ Skolnick, Justice Without Trial, stpra note I, at 42-48,63-64; WiLson, Varieties of Police BeHavior, supra note 30 , at I9-20.

${ }^{50}$ Sibron v. New York, 392 U.S. 4I, 65 (1968); see also Tenry v. Ohio, 392 U.S. I (I968). 
not going to be very concerned with the legal criteria for probable cause or with the distinct possibility that the evidence might be excluded in court.

3. Obtaining Information. The police have particular trouble obtaining information about some crimes whose solutions are very important to them. This is particularly true for crimes without victims. Rules limiting searches and seizure of evidence as well as those regarding interrogations are part of these obstacles to information gathering. .1 $^{51}$

Whether they result from substantive laws whose violations are hard to observe or from procedural restraints imposed by courts, these difficulties lead the police to make certain trade-offs. One of the most important involves obtaining evidence illegally either by search or interrogation in minor cases in order to obtain evidence for a more important case. This is a frequent practice in narcotics cases. The police have great control over the amount of information and the way it is presented to those most directly involved with charge and prosecution. Although courts may require that the police identify the source of information, the police will often circumvent this requirement by using the evidence only for information. ${ }^{\mathbf{2}}$

4. Harassment. Harassment is another objective that may not involve arrest or may involve arrest without concern with prosecution. It is sometimes difficult to separate harassing behavior from activities related to goals of authority-maintenance, self-protection, or information-gathering. Nonetheless, there is ample evidence showing that police officers stop, question, and threaten people with arrest, or in fact arrest them, because they do not like their life style or political views. ${ }^{53}$

The importance of officer discretion helps to explain two important findings regarding the impact of Court-imposed rules. First, persons suspected of more serious crimes are more likely to receive the Miranda warning, particularly in situations where the police have enough evidence to go to trial but perhaps not quite enough for conviction. ${ }^{54}$ This is consistent with the contention that rules are more likely to be followed where arrest and prosecution are desired and where the police feel the avoidance of the rules would limit such prosecution.

\footnotetext{
${ }^{51}$ Forty per cent of those who felt that court search and seizure decisions caused problems and $50 \%$ of those who felt that way about interrogations claimed that the decisions created problems for information gathering. These responses are the most frequent. Reiss, supra note 8, at 110-II. Informational difficulties may also lead to increased harassment. See Reiss \& Bordua, stpra note I, at 145; Lindesmitu, supra note 2I; Skolnick, Coercion to Virtue, supra note 14 , at 628-29.

${ }^{68}$ SKolmicr, Justice Without Trial, supra note $\mathrm{I}$, at 133-36.

${ }^{63}$ For examples see Gallo, Mason, Meisinger, Robin, Stabile, \& Wynne, The Consenting Adult Homo* sexual and the Law: An Empirical Study of Enforcement and Administration in Los Angeles County, I3 U.C.L.A.L. Rev. 643, 686-742 (I966). See also P. CFEvigny, Police Power (x969). The use of selective enforcement policies as a means of harassing individuals because of their political beliefs is shown in Heussenstamm, Bumper Stickers and the Cops, Trans-Acrion, Feb. 1971, at 32.

${ }^{8}$ Wald, supra note 42 , at I552-54. In their finding that police are more likely to obtain search warrants where there is need for simultaneous and organized raids, Tiffany et al. suggest another way the seriousness of a crime relates to a concern with legality. The use of search warrants under these circumstances suggests that police may be more likely to use warrants against individuals who are suspected of being part of complex and bureaucratic criminal organizations. TIPFANY, McINTYRE, $\varepsilon$ ROTENBERG, supra note 21 , at 99-II9.
} 
The second finding concerns the distinction the police make between the extent to which various parts of the rules affect their job. Survey data show that the police are more upset by perceived Court limitations on searches than they are by the limits against the seizure of evidence. Sixty-one per cent saw problems created by Supreme Court decisions concerning searches, while only $4^{8}$ per cent felt that way about limitations on the seizing of evidence. Similarly, 70 per cent saw problems because of Court-imposed limits on interrogations, as compared to the complaints of only 45 per cent about the limits upon' the use of confessions. ${ }^{55}$ Both interrogation. and search are important tactics for police behavior involving goals in addition to arrest and successful prosecution. Seizure and confession, however, are less important since they are really relevant only to the objectives involving arrest and successful prosecution.

Police discretionary behavior also mitigates the legal rules' effectiveness even when the arrest-prosecution goal is paramount for the police. The police officer may use the strategies he has at his disposal to make unconstitutional behavior take on the appearance of legality. The ability to do this successfully is related to his isolation and to his previously discussed control over the process of furnishing information to other participants in the administration of criminal justice. This is true in regard to both search and interrogation behavior.

According to the present law of arrest, an officer must have reasonable or probable cause for making an arrest. A search without warrant is permissible only if it is incident to such valid arrest. Police officers find this rule to be a potentially severe obstacle because they typically find themselves in situations where they believe search is first required to gain evidence necessary to justify the arrest. To overcome these obstacles, the officer reconstructs the circumstances of the arrest in such a way that it fulfills the criteria of probable cause. This is not as much an outright fabrication as it is a rearrangement. The offeer will avoid this behavior if he can, but, in Skolnick's words, “. . . when he sees case law as a hindrance to his primary task of apprehending criminals, he usually attempts to construct the appearance of compliance, rather than allow the offender to escape apprehension."56 One study of the impact of Mapp shows that there was almost no increase in the percentage of search and seizure cases decided in favor of the defendant during the first two and one-third years after that decision ( 26 per cent), as compared to those so decided in the three years prior to $M a p p$ (24 per cent). ${ }^{57}$ From this study it is possible to infer increased police compliance with the rules imposed by the Court, especially since other data in the same study suggest that judges were not making it easier for the police by making their standards of legality more lenient. ${ }^{58}$ In light of the previous discussion, however, it is also possible that these findings indicate successful police attempts to overcome the decision's obstacles.

\footnotetext{
${ }^{50}$ Reiss, supra note 8 , at Iro-r 3 .

${ }^{50}$ SkOlNick, Justice WIthout Trual, supra note I, at 215. See also id. at 2II-Ig.

${ }^{7}$ S. Nagel, The Legal Process from a Behavioral Perspective 302 (I969).

${ }^{58} \mathrm{Id}$. at 300 .
} 
Similarly, police officers reconstruct formal records of interrogation so that questionable techniques used to obtain waiver of Miranda rights do not appear in the formal record. The formal record will only contain the interrogator's warning and a waiver by a defendant who in fact had earlier waived his rights and had been interrogated during previous unrecorded interrogations. ${ }^{59}$

Again, it is important to note that police organizations at least tacitly approve of such discretionary behavior by rewarding the officer not for his consistency with legal procedures but for his ability to clear cases by means of arrests.

\section{Clientele Hostility and Dependence}

Much of the previous discussion, particularly the discussion of authority, touched upon the importance that hostility plays in police decision-making. Briefly, police concern about controlling situations in order to minimize hostility increases the likelihood that police will behave in ways that lessen the effectiveness of legal rules. ${ }^{00}$ Here a few more words need to be added about another common characteristic of police-citizen interaction, client dependence.

The relationships between the police and their clientele are more diffuse and less voluntary than those of other occupations. Just as in some situations this diffusiveness and involuntariness can increase hostility, in others these characteristics lead to clientele humiliation that fosters dependence on the police officer's definition of the situation. This is more likely when a citizen is isolated from his peers, friends, or family. ${ }^{61}$ Situations involving search and particularly interrogation typically create such dependence. ${ }^{62}$

The citizen's fear, combined with his lack of information, makes him more receptive to police suggestions. The police frequently justify searches without warrant on the grounds that the suspects gave consent to such searches. One can cynically interpret this as "offensive to common sense and human experience to believe that such offenders would consent to a search knowing the police officers

\footnotetext{
${ }^{50}$ See, e.g., Mrlner, The Court and Local Law Enforcenent, supra note 6, at $21 \mathrm{1}$. In $196 \mathrm{r}$ the Detroit police obtained confessions in $6 \mathrm{r} \%$ of the felony prosecutions. They were deemed cssential for prosecution in $13 \%$ of the felony cases. In 1965 after the police began advising suspects of their right to remain silent and to have counsel, the percentage of confessions dropped only slightly to $58 \%$ and the percentage of "necessary" confessions dropped only slightly to $1 \mathrm{r} \%$. Souris, Stop and Frish or Arrest and Search-The Use and Misuse of Euphemisms, 57 J. CRIM. L.C. \& P.S. 25I, 255 (1966). Souris secms sanguine in his interpretation of these data. He claims that the drop in necessary confessions from 13 to $\mathrm{Ir} \%$ reflects greater reliance on other methods of investigation. This change is too insignificant to warrant such a conclusion.

${ }^{\circ 0}$ For further discussion of client hostility, see Wilson, Varieties of Police Beinavion, supra note 30, at 26, and Reiss \& Bordua, supra note $x$, at 30,47 .

${ }^{1}$ See also Hudson, supra note $\mathrm{x} 6$.

62 This has increasingly become an important factor in the Supreme Court's decisions regarding police interrogation. See MrLner, The Court and Local LAW Enforcement, stipra note 6, at 26-47. In a recent case the Court has somewhat clarified its position on the importance of isolation to the coerciveness of interrogations. In that case the Court said that it is not just the familiarity of the surroundings but the suspect's freedom to leave that determines whether or not interrogations are custodial and thus require the Miranda warning. Orozco v. Texas, 394 U.S. I (1969).
} 
will find contraband." ${ }^{\text {"3 }}$ Yet suspects frequently waive their rights because they feel they have no choice or because they do not understand the implications of doing so. In situations involving search, the police take advantage of this dependence by confidently taking initiative and giving the citizen the impression he can do nothing about it. ${ }^{64}$

Similarly, virtually all studies of the impact of the Miranda decision show that such client characteristics are important factors in explaining why so few suspects request counsel and why the number of incriminating statements did not decrease after the decision. ${ }^{65}$ The suspect may have cognitive understanding of his rights, but he may lack appreciation of them and the ability to apply them to their crisisladen situation. ${ }^{66}$

\section{III}

\section{Reference Groups}

Though the preceding analysis suggests that the police have a great deal of control over the standards of legality they follow, the development and acceptance of these standards are also affected by other groups and agencies involved in the administration of criminal justice. Such groups can play a role in formulating standards of legality and in punishing or otherwise discouraging police behavior contrary to these formulated standards. ${ }^{67}$ In fact, there are several important reasons why these reference groups frequently reinforce or accept police interpretations of legal standards.

There are two characteristics of the relationship between police and their reference groups that mitigate the effectiveness of legally imposed constraints. First, police departments are generally quite isolated from groups whose views differ from their own. Those concerned with police department innovation argue that this type of isolation is an important reason for police resistance to change. ${ }^{68}$ Second,

\footnotetext{
${ }^{03}$ TiffanY, MCINTYRe \& RotenberG, supra note 2I, at 156.

${ }^{04}$ Id. at $156-70$.

${ }^{00}$ See, e.g., Wald, supra note 42, at 1552-78; MiLner, The Court and Local Law Enforcement, stspra note 6, at 208-23; Leiken, Police Interrogation in Colorado: The Implementation of Miranda, 47 DENVER L.J. I (1970). Medalie, supra note 42, at I4I4, offers the best evidence of the lack of change in the number of incriminating statements the police obtained after Miranda. Forty-three per cent of the suspects gave such statements during the year prior to Miranda, while $40 \%$ gave these statements during the six months after the decision was handed down. Furthermore, only $2 \%$ of those charged with felonies or serious misdemeanors during the period of this study requested counsel despite the fact that volunteer attorneys were available 24 hours a day. One could view the decision not to use an attorney as a rational and calculating one, but the evidence cited earlier in this footnote suggests other. wise.

${ }^{60}$ Medalie, supra note 42.

or The communication process at this level is discussed in LaFave \& Remington, Controlling the Police: The Judge's Role in Making and Reviewing Law Enforcement Decisions, 63 Mich. L. Rev. 987 (1965); Mrlaner, The Court and Local Law Enforcement, supta note 6, at 8I-I86. The obstacles to communication is an important theme of President's Commisston on Law ENFoRcement AND tHe ADministration of Justice, Task Force Report: The Police (1967) [hereinafter cited as President's Commission].

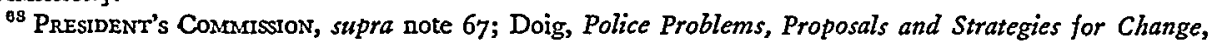


the police are an integral part of a system the actual operation of which is characterized by far more cooperation among participants than the adversary model suggests. ${ }^{69}$

In this context we shall investigate three of the mitigating characteristics of police-reference group relations: reinforcement of existing distrust of legal and social change, training police to interpret Court decisions narrowly, and the acceptance and sanction of police definitions of legality that are contrary to constitutional standards.

\section{A. Reinforcement of Distrust}

Police tend to be most influenced by organizations that foster or reinforce the distrust as discussed in part I. The Federal Bureau of Investgiation is most effective in furnishing the police with information about legal and social change. Indeed it has played an important role in modernizing police departments. Through its role in local police training programs and through FBI publications, the Bureau has a good opportunity to assist police in defining social reality. Its view of social reality, however, rather indiscriminately sees liberal social reformers, whether their concern is crime or social welfare measures, as a threat to the police occupation. These reformers, who include supporters of the Supreme Court's due process-oriented decisions, are viewed as at best misguided individuals whose sympathy toward the criminal poses a direct threat to society and who thus play into the hands of subversive elements. It is doubtful that the FBI initially introduces such views, but one can say that these views of social reality are at least consistent with that of the police occupational ideology. ${ }^{70}$

\section{B. Instructing Police to Interpret Decisions Narrowly}

Because of the isolation of the police, it should not be surprising that the FBI is also the single most important police reference group for information about Court activities. The Bureau has an expert on police education who prepares materials for use by local agents and by the police departments' own training officers in teaching the rank and file police about Supreme Court decisions. The materials

28 PUB. AD. Rev. 393 (I968); for discussions of police isolation see Muir, stupra note I3, and Hudson, supra note 16 . For a general diseussion of group influence on legal change, see Evan, Law as an Instrument of Social Change, in AppiIEd SocioLogy 285-9r (A. Gouldner \& S. Miller eds. I965).

${ }^{60}$ Skolnick, Social Control in the Adversary System, II J. Confzict Resolution 52 (1967); Mileski, Courtroom Encounters: An Observational Study of a Lower Criminal Court, 5 Law \& Soc'x REv. 473, 496-97 (I97I).

${ }^{70}$ See Polmics of Protest and other sources cited in note 22 supra. This view of social reality and its accompanying ideology were, of course, publicly advocated by J. Edgar Hoover, but Hoover's influence in increasing the right-wing tendencies of the police should not be overemphasized. Indeed this police-FBI ideology, with its emphasis on moralism, good versus evil, and individual morality is similar to right-wing extremist ideology, at least as it is defined by a recent seminal work on the subject. But the existence of these views of social reality seem to predate the existence of either Mr. Hoover's or the FBI's influence. Police were particularly active in the Ku Klux Klan in the I920's, and the antiSemetic Christian Front in the I930's, and they are the one low status group prevalent and active in the John Birch Society. See S. IIPSET \& E. RAAB, The Politics of Unreason 124, 177, 317-18 (1970). 
prepared in response to Miranda suggests how FBI-influenced training might limit the effectiveness of formal legal rules.

Much of this material is devoted to a clear an'd concise summary of the decision, but the crucial portions emphasize ways of mitigating Miranda's constraints, as the following statement demonstrates:

Particular caution is necessary if the interrogation of a criminal suspect in a law enforcement office is to be kept noncustodial so that the Miranda warning and waiver procedure need not be followed. The invitation to the office should be handled in such a way that it clearly is an invitation, not a command, order, or arrest. A true invitation can be extended by mail, telephone, or friend. The officer can personally contact the suspect and accompany him to the office if he is willing to go. ... Once the invited suspect reaches the law enforcement office, the conditions of the interrogations should be kept as noncustodial as possible. Allow him all available courtesies, such as permission to use the telephone. If the facilities are suitable, conduct the interrogation in some semipublic place such as a desk in the corner of the police department lobby, or in a large room where other desks are occupied by police clerical personnel in the performance of their regular duties. ${ }^{71}$

The emphasis here is clearly on ways to maintain pre-Miranda procedures and to avoid advising the person of his rights to remain silent and to have counsel. Though it stresses the distinction between custodial and noncustodial interrogation, one should note that the word "suspect" is used to describe even those undergoing interrogation that is supposedly noncustodial. A study of the FBI's influence regarding the interpretation of Miranda showed that the police department most thoroughly exposed to such material was most likely to recognize the limits of the Miranda constraints on police behavior. ${ }^{2}$

\section{Acceptance of Police Definitions of Legality}

The acceptance of the police definition of legality is directly related to the lack of adversariness in the criminal justice process. For example, plea bargaining offers the prosecutor the opportunity to settle for conviction on a lesser charge in cases where he believes evidence obtained through searches and interrogations would be successfully challenged if the case went to trial. ${ }^{73}$ But even if a case involving illegally obtained evidence does get to court, and even if the judge suspects that the evidence was illegally obtained, there are some everyday pressures that limit the judge's willingness to penalize this behavior.

For example, the juvenile court judge views a youth's verbal denunciation and other threats to police authority as a basic threat to the authority of the entire juvenile justice system. Consequently, the judge may conduct hearin'gs in a way that protects the legitimacy and authority of the police even when police violate

\footnotetext{
71 D. Dalbey, Police INterrogation Supplement 9-io (1967). Emphasis is in the original.

72 Milner, The Court and Local Iaw Enforcement, supta note 6.

${ }^{3}$ Admittedly, the evidence on this point is only suggestive. See D. OARs \& W. Leman, A CrIminal Justice System and the Indigent: A Study of Chicago and CoOK County 72-8I (1968).
} 
legal rules. ${ }^{74}$ Even if he dismisses the charges, the judge blames dismissal on the legal technicalities imposed by the courts an'd not upon the actions of the officer. ${ }^{75}$ The non-juvenile court might not emphasize the importance of authority to this same degree. Nonetheless, there is good evidence showing that a symbiotic relationship between judge and police exists in non-juvenile courts and that this relationship is protected by the judge's acceptance of police definitions of legality. ${ }^{70}$

The lack of adversariness of the process further mitigates the rules' effectiveness because the process discourages an attorney from challenging police practices. It is difficult to determine the number of cases that go unchallenged for these reasons, but the combined evidence of at least three studies suggests that this reluctance is important. On the basis of detailed observations of a single police department in a large city, Skolnick concluded that defense attorneys are commonly impressed with the incriminating evidence and are not likely to challenge. Skolnick considers this reluctance to be one of the key factors mitigating the effectiveness of the exclusionary rule. ${ }^{77}$ A study of the impact of Miranda showed that the presence of counsel did not reduce the likelihood that a suspect would make an incriminating statement. In fact those with counsel were slightly more likely to furnish such statements. While 49 per cent of those with volunteer defense attorneys and $4 \mathrm{I}$ per cent of those with their own attorneys made statements, only 39 per cent of those without counsel did so. ${ }^{78}$

Again, caution must be exercised in these inferences. These data alone do not show that defense counsel directly sanction police definitions of legality that are less stringent than the Court's. Still, a defense attorney has important reasons of his own for avoiding conflict with judges and prosecutors. ${ }^{79}$ Other observations of the attorney's role in' a non-adversary system are more explicit on this point. The following comment of a defense attorney shows how the importance of an attorney's

\footnotetext{
${ }^{74}$ R. Emerson, Judging Delinguents: Context and Process in Juvenile Court 50-5i (1967).

${ }^{75}$ Id. Though this study deals only with juvenile courts it is important because of its concern with standards of search and interrogation that now apply to juvenile as well as adult courts. See In re Gault, 387 U.S. I (1967). For a study of the impact of Gault that considers some of these factors, see Tefstein, Stapleton, \& Teitelbaum, In Search of Juvenile Justice: Gault and Its Implementation, 3 LAW \& Soc'Y REv. 49I (I969).

${ }^{78}$ Chevigny, supra note 53; A. Blumaberg, Criminal Justice ch. 4 (1967). A recent issue of the police periodical, Law and Order, gives a rather bizarre example of a judge's effort to protect police authority from verbal abuse. In that case a judge sentenced a person to three hours in a pig pen for calling a policeman a pig. The magazine's editorial supporting the judge nicely captures the perceptions of the importance of authority and deference:

"It would be helpful if the courts would mete out similar sentences to people who rcvile police officers. Name calling would be minimized, lessening verbal confrontations which invariably become heated and erupt into violence.

"Perhaps the law cannot legislate respect, but the courts can aid the police by publicizing the penalty for using abusive language to [sic] an officer." Three Hours in a Pig Pen, LAw and Onden, July, I97r, at 6 .

${ }_{77}$ SkOLNICK, JUSTICE Without TrIAL, supra note I, at 224.

${ }^{78}$ Medalie, supra note 42 , at 1414 .

${ }^{70}$ Blumberg, The Practice of Law as a Confidence Game: Organizational Cooptation of a Profession, I LAW \& SOC'Y REv. 15 (1967).
} 
relationship with the prosecutor may increase his willingness to accept evidence that he admits is illegally obtained:

"Sure I could start to negotiate [in a plea bargaining situation] by saying, ' $\mathrm{Ha}$, hal You goofed. You should have given the defendant a warning.' And I'd do fine in that case, but my other clients would pay for this isolated success. The next time the district attorney had his foot on my throat, he'd push too." 80

\section{ConCLUSION}

Students of legal change too often approach their subject matter with an implicit belief that legal rules will have some significant effect and that noncompliance is aberrant. This perspective leads to an over-emphasis on the effectiveness of formal legal rules. ${ }^{81}$ Viewing the police as a bureaucracy that, like other bureaucracies, contains an inherent tension between the introduction of new formal rules and their implementation helps to correct this bias. This is most certainly not to say that we must necessarily tolerate such behavior, but only that the perspective emphasizing the police organization helps us to understand the process involved. In short, the perspective is a good one if we avoid minimizing the police officer's and the police organization's ability to limit the effect of legal rules.

There are two very significant reasons why an explanation of police behavior that stresses similarities with other bureaucracies minimizes police effectiveness in limiting legal change. The first relates rather directly to the evidence presented in this essay; there seems to be an exceptional degree of hostility, distrust, isolation, and discretion within the police departments. Other bureaucracies may also be extremely hostile, distrustful, and isolated, but the police seem to be more so. (Comparative studies of various bureaucracies' reactions to Court decisions would be very valuable on this point.) The second reason is more subtle but perhaps far more important. Quite simply, society may set more rigorous standards for police behavior because of the particular importance the issue of police restraint plays in the lives of citizens. The Court's attempts to regulate police behavior are aimed at guaranteeing the citizen's most basic safeguard against police overzealousness and, by extension, against a police state. That safeguard is the right to remain free from arbitrary police suspicion. David Matza eloquently describes the basic importance of this right:

However important the protection afforded by the promise of civil rights, it is augmented by a more basic safeguard. The more important way in which a citizen's rights are protected is the expectation that under ordinary circumstances he will remain above suspicion. ... The protection of due process is at best a procedural probability; immunity from suspicion is substantial and certain because of its

\footnotetext{
${ }^{80}$ Alschuler, The Prosecutor's Role in Plea Bargaining, 36 U. CHr. L. REv. 50, 80 (Ig68).

${ }^{81}$ See Levine, stpra note 3; Skolnick, Jusnce Without Trial, supra note I, at 219; Wasby, The Supreme Court's Impact, 5 LAw \& Soc'x REv. 4r, 49 (1970).
} 
absence. The absence of [police] penetration protects us from finding out whether due process is full reality. ${ }^{82}$

The irony, of course-indeed the irony that encapsulates the reasons why legal rules are mitigated-is that by using the exclusionary rule the Court depends upon sanctions that force the citizen to depend upon due process constraints. The Court adopted the exclusionary rule as a primary means of sanctioning police behavior not because it had any great faith in the rule's efficacy but because no other legal sanctions had worked. "There is little doubt that, if this were the best of all possible worlds the exclusionary rule would make little sense for it imposes no direct sanctions against the police wrongdoers."83

Changes that are necessary to make the exclusionary rule unnecessary may be so basic as to require the adoption of a new paradigm of criminal justice administration, a paradigm emphasizing the values and norms necessary to gain police restraint. ${ }^{84}$ It is far beyond the scope of this essay to develop strategies required to accomplish this; however, one can certaintly say that the acceptance of this paradigm requires that society itself be more willing to encourage police restraint. ${ }^{85}$ Skolnick asserts, for example, that the police will not adopt a view of professionalism that stresses restraint until others in society as well as the police accept the notion that the philosophy of professionalism

must rest on a set of values conveying the idea that the police are as much an institution dedicated to the achievement of legality in society as they are an official social organization designed to control misconduct through the invocation of punitive sanctions. ${ }^{86}$

At the very minimum this would seem to require that groups outside the police organization more actively encourage police restraints. Existing reference groups might advocate this goal more explicitly, or new groups might become a more integral part of the process. In any case such exchanges in police behavior are unlikely unless other changes in the criminal justice system take place.

The importance of the Court's attempts at police restraint may pale in this context, but it might still play some role. Though the Court's power to develop a conscious and explicit program seems effectively limited, this institution might still influence attitudes and behavior in other ways. It may act as a catalyst for change by lending its prestige to certain values and thus encouraging interest

\footnotetext{
${ }^{82}$ MATZA, supra note 39 , at I82-83.

${ }^{83}$ Chambliss \& Seidman, supra note 5, at 238-39.

8t The seminal discussion of the relationship between change and the adoption of new paradigms is T. Kunn, The Structure of Scientific Revolutions (rg62). Another brief general discussion can be found in G. Swanson, Social Change I22 (I97I). For a discussion of legal procedural reform in these terms, see E. Lemert, Soctar Action and Legai Change: Revolution Within the Juvenite Court (1970). See also Skolnick, The Police and the Supreme Court, in Southern Recional Education Board, Report No. 7, Administration of Criminal Justice (1967).

${ }^{86}$ Chambliss \& Seidman, supra note 5, at 250-39r, uses a form of social class analysis to discuss society's views of police restraint.

${ }^{80}$ Skolnick, JUStice WIthout Triat, supra note $\mathrm{I}$, at 238-39.
} 
and support from others in a better position to develop programs necessary to implement these values. ${ }^{87}$

Yet even this view of the Court may be unduly generous about its influence on police restraint. Recent history of the involvement of other institutions in criminal justice innovation suggests that they indeed react to the Court's interest in police restraint, but in ways contrary to the Court's goals. There is an explicit and conscious attempt to mitigate the Supreme Court's effectiveness. ${ }^{88}$ Finally, the Court itself may have begun to decrease its emphasis on due process constraints. ${ }^{89}$ If this is indeed the case, the Supreme Court, while perhaps not explicitly overturning the exclusionary or the Miranda rules, nonetheless may have begun to lend its prestige to goals and ideologies that further limit the rules' support.

\footnotetext{
${ }^{87}$ Levine, supra note 3, at 587; Grossman, The Supreme Court and Social Change: A Preliminary Inquiry, I3 ABS 535,545 (1970). Students of the Supreme Court have generally ignored the study of these kinds of dynamics. We know very little about what Becker calls the "relative impact" of the Court. See T. Becker, Contparattve Judicial Politics 360-6I (I97I).

${ }^{88}$ R. Hiarris, The Fear of Crime (ig68).

${ }^{80}$ See, e.g., Harris v. New York, 40I U.S. 222 (I97I).
} 